\title{
European Governance of Health Systems. It Takes Two to Tango: The Council of Europe and the European Union
}

In the European health field, the Council of Europe ${ }^{1}$ and European Union ${ }^{2}$ are the major players. ${ }^{3}$ The organisations share the same fundamental values of human rights, democracy and the rule of law. The Council of Europe has coordinated inter-governmental co-operation in the field of health among its member states since 1954. Protection and promotion of health is an important aspect of the organisation's human rights mandate. The European Union (EU, a political and economic organisation) aims to ensure good healthcare, to protect and improve human health and to support the modernisation of Europe's health systems in order to ensure their accessibility, effectiveness and resilience. ${ }^{4}$

The EU 'Strategic Framework and Action Plan on Human Rights and Democracy 2012-2019'5 indicates that the prospect of the EU's acceptance of the jurisdiction of the European Court of Human Rights, through its accession to the European Convention on Human Rights, underlines the EU's commitment to human rights in all spheres.

In relation to health and healthcare, the organisations have a close relationship. Their official co-operation dates back to 1985. Joint Declarations stress

1 CoE: 48 Member States.

2 EU: at present 28 Member States.

3 The United Nations (UN), World Health Organisation (Regional Office for Europe), Organisation for Economic Co-operation and Development (OECD) are also of importance for European health policies.

4 The EU third health programme (2014-2020) focuses upon four themes: 1. Promote health, prevent disease and foster healthy life styles through 'health in all policies'; 2. Protect EU citizens from serious cross-border health threats; 3 . Contribute to innovative efficient and sustainable health systems; 4 . Facilitate access to high quality, safe healthcare for EU citizens.

525 June 2012, adopted by the Council on 20 July 2015 (Соном 81).

(C) HENRIETTE D.C. ROSCAM ABBING, 2018 | DOI 10.1163/15718093-12502001

This is an open access article distributed under the terms of the prevailing CC-BY-NC license at the time of publication. 
the importance of harmonisation at the level of both European institutions and at national level. Joint programmes have been developed since $1993 \cdot{ }^{6}$

The Council of Europe's European Convention for the Protection of Human Rights and Fundamental Freedoms (ECHR, 1950) includes various healthrelated clauses (notably the right to life, the right to protection of the personal sphere and the prohibition of torture and maltreatment). The Convention on Human Rights and Biomedicine (Oviedo Convention, 1997) is a health sector specific human rights convention. Protocols to it (four at present $)^{7}$ develop the principles of the Convention in specific fields.

The jurisprudence of the European Court on Human Rights has an important impact on national health policies. The Court may also give advisory opinions on legal questions concerning the interpretation of the Biomedicine Convention.

The Council of Europe's European Social Charter (ESC, 1961) revised in 1996, includes a number of health-related provisions. The European Committee of Social Rights monitors compliance with the Charter under two complementary mechanisms: a collective complaints procedure ${ }^{8}$ and a Reporting System. ${ }^{9}$ Decisions and Conclusions of the European Committee of Social Rights must be respected by the States concerned. As such, they provide the basis for developments in social rights through legislation and case-law at national level.

The entry into force in 2009 of the EU Charter of Fundamental Rights as a binding legal act did not deprive the ECHR of its place in the EU legal system as a source of fundamental rights in the form of general principles. ${ }^{10}$ Irrespective the fact that the $\mathrm{EU}$ is not (yet) formally a party to the Council of Europe human rights instruments, ${ }^{11}$ the ECHR and the European Social Charter are

6 A Memorandum of Understanding was signed in 2007. EEAS.EUROPA.EU.

7 Prohibition of cloning human beings, Transplantation of organs and tissues of human origin, Biomedical research, Genetic testing for health purposes.

8 Collective complaints lodged by social partners and other non-governmental organisations.

$9 \quad$ National reports drawn up by Contracting Parties.

10 Charter of Fundamental Rights of the European Union, Preamble.

11 Cases cannot be brought in the ECtHR against the European Union, but the Court has ruled that states cannot escape their human rights obligations by saying that they were implementing EU law. The European Court of Justice (ECJ) gives the European Convention on Human Rights "special significance" as a "guiding principle" in its case law. 
frequently referred to in EU texts. They are acknowledged as a recognised level of protection of the EU Member States. ${ }^{12}$ EU research and innovation activities funded under the EU HORIZON 2020 must comply with the ECHR and its supplementary Protocols.

However, to date, the EU is not a Party to the ECHR. Accordingly, its acts cannot as such be the subject of applications to the European Court of Human Rights (the Court). Nevertheless, cases relating to Community law have been regularly raised with the Court. In "Bosphorus Airways" v. Ireland, the European Court of Human Rights considers that "the protection of fundamental rights by Community law [is] ... 'equivalent' ... to that of the Convention system". The Court also ruled that States cannot escape their human rights obligations by saying that they were implementing Eu law. ${ }^{13}$

As to the Council of Europe's European Social Charter, the European Social Committee, charged with its supervision, routinely assesses whether national measures implementing EU law are compliant with the ESC. The ECJ on the other hand scarcely makes use of the Committee's decisions as a source of inspiration when it comes to health-related matters. This despite the fact that the EU Member States are all members of the Council of Europe. Thus, they are part of the "system" of the European Social Charter Treaties, albeit with differences among the EU Member States regarding the commitments they have entered into. ${ }^{14}$

\section{Council of Europe and European Union: Complementarity and Partnership}

Although distinct organisations as to their respective roles and design, in the field of health and health-related human rights, in many ways the roles of the Council of Europe and the European Union are complementary. The 'points of contact' include subjects covered by Protocols to the Convention of

The EU's Treaty of Lisbon, in force since 1 December 2009, requires accession by the EU to the ECHR (Article 6 of the consolidated Treaty on European Union): "The Union shall accede to the European Convention for the Protection of Human Rights and Fundamental Freedoms. Such accession shall not affect the Union's competences as defined in the Treaties." On its turn, Protocol No. 14 of the ECHR (entrance into force 1 June 2010) allows the European Union to accede to the European Convention on Human Rights.

12 Art. 53 Charter Fundamental Rights.

13 'Bosphorus Airways' v. Ireland (no. 45036/98), Judgment (Grand Chamber) of 30 June 2005, case law concerning the European Union, EcrtHR, Factsheet, April 2017, p. 3.

14 The 1961 Charter, Additional Protocols to it of 1988 and 1995 and Revised Charter of 1996. 
Human Rights and Biomedicine. Besides the advantage of having a broader geographical reach, the Council of Europe, with its human rights instruments and through its soft law ${ }^{15}$ may provide for more ample protection than EU legislation. Pertinent examples of this complementarity are in the field of genetic testing ${ }^{16}$ and on health data protection. ${ }^{17}$

Another example of co-work between the Council of Europe and the European Union is the Handbook on European Data Protection Law (2014), jointly prepared by the European Union Agency for Fundamental Rights (FRA) and the Council of Europe, together with the Registry of the European Court of Human Rights. A new version of this Handbook is under way. The book will include key aspects of the European legal framework, both at the Council of Europe and European Union levels. The Handbook will become the main point of reference on European data protection law, including the 2016 EU Regulation on Data Protection Law. ${ }^{18,19}$ This is of importance, if only because the EU Regulation allows for a number of derogations from patients' rights to access one's data, to have those data rectified, and to seek consent for secondary research use. Such a publication will give insight in the differences in implementation by EU Member States. National differences in the use of research data may hamper, instead of facilitate, research co-operation in Europe. EU citizens' insight in those differences is also of importance in the context of cross-border healthcare.

15 Complementarity often takes the form of recommendations. Next to the Council of Europe'sCommittee of Ministers recommendations in the field of blood transfusion and transplantation of organs, they include recommendations on genetic testing and screening for health care purposes (Rec. 92(3), on the protection of medical data, Rec. 97(5), on xenotransplantation (Rec. 2003(10), on the protection of the human rights and dignity of persons with mental disorder (Rec.2004(10), on research on biological materials of human origin (Rec.2006(4), on the processing of personal data in the context of employment (Rec.2015(5) and on processing of personal health related data for insurance purposes, resulting from genetic tests Rec.2016(8).

16 On genetics, see also Henriette Roscam Abbing, 'Editorial: New EU rules for in vitro diagnostic genetic tests, a first step in the right direction', EJHL 24 (2017) 121-133; Calum Mackellar, 'Can maternal spindle transfer and pronuclear transfer be prohibited under EU legislation?', EJHL 25 (2018) 57-74.

17 See supra note 15.

18 General Data Protection Regulation, (EU) 2016/679).

19 European Union Agency for Fundamental Rights, Update of Handbook on European Data Protection Law, European Agency for Fundamental Rights website, under projects. 
Less well-known is the 'Partnership for Good Governance' between both organisations in the health field. ${ }^{20}$ This co-operation dates back to 1985 . Joint programmes in the context of this partnership (based on co-funding) have been developed since $1993 .{ }^{21}$ With the signing of a Memorandum of Understanding by the Council of Europe and the EU in 2007, inter- institutional co-operation in the areas of common interest has been enforced and has become more systematic. Human rights and fundamental freedoms, ${ }^{22}$ as well as social cohesion are part of the shared priorities.

\section{4}

\section{The European Directorate for the Quality of Medicines and Health Care (EDQM)}

The European Directorate for the Quality of Medicines and Health Care (EDQM) - created in 1964 at the Council of Europe in close co-operation with the $\mathrm{EU}$ - is another example of the partnership between both organisations. The Directorate contributes to the basic human right of access to good quality medicines and health care, and promotes and protects human and animal health. ${ }^{23}$ The EDQM respects fundamental rights, observes the principles reflected in the EU Charter of Fundamental Rights and takes into account the Convention of Oviedo. ${ }^{24}$

20 Memorandum of Understanding between the Council of Europe and the European Union, signed 11 May 2007. The Memorandum is in line with the joint co-operation and partnership signed 1 April 2001 (EU enlargement regions, Eastern Partnership and Southern Mediterranean Countries).

21 The current joint programme of six years (2014-2020) addresses health and wellbeing of youth, and more specifically human rights and health care in prisons in Georgia.

22 The European Union regards the Council of Europe as the Europe-wide reference source for human rights. In this context, the relevant Council of Europe norms will be cited as a reference in European Union documents. The decisions and conclusions of its monitoring structures will be taken into account by the European Union institutions where relevant. The European Union will develop co-operation and consultations with the Commissioner for Human Rights with regard to human rights.

23 The European Medicines Agency (EMA, EU) and the EDQM (Council of Europe) cooperate on matters aimed at ensuring the quality of medicines and protecting public health.

24 The EU Charter of Fundamental Rights nor the Convention of Oviedo make express provision for harmonisation or prevent Member States from introducing more stringent requirements in their legislation. 


\subsection{Medicinal Products}

The EDQM represents the European Pharmacopeia in the harmonisation process of the three major pharmacopeias (European, Japanese, and USA), and participates in the international conference of the harmonisation of the testing of medicines, set up in 1990. Standards are a vital instrument for registration, market surveillance, and free movement and trade of medicines among as many countries as possible. Thanks to this programmatic co-operation between the Council of Europe and the European Union, duplication of activities is avoided, while time required for innovative medicines to become available is saved. The present structure is also cost effective.

The EDQM also works with national, European and international organisations in efforts to combat the counterfeiting of medical products and similar crimes. Counterfeit medical (health) products can have harmful effects on patients' health. The use of the internet contributes to the growth of this problem. To ensure the quality and safety of medical products, the EDQM has developed a global strategy against falsification; it plays a major role in implementing and monitoring the Council of Europe's Convention on the counterfeiting of medical products and similar crimes involving threats to public health, medicines and medical devices. ${ }^{25}$ The European Directorate also provides for policies and model approaches for the safe use of medicines, including guidelines on pharmaceutical care. Where patients must have access to safe and appropriate medicines in a time of increased cross- border accessibility of medicines through the application of new IT technologies, harmonised provisions and conditions for safe use of prescription and non-prescription medicines are indispensable. ${ }^{26}$ The conditions vary considerably between European countries, due to different interpretation and implementation of the $\mathrm{E} U$ legislation. Shortcomings in the harmonisation of important additional classification criteria and differences in medical practice also play a role. Hence the increased importance of substantial harmonisation of national legislation regarding the supply of medicines obtainable on medical prescription. For this purpose, Resolution (2007) 1 about the classification of medicines concerning their supply (prescription only) requires annual revision. This European harmonisation

\footnotetext{
25 Medi-Crime Convention, entered into force in 2016.

26 The classification into 'Over the Counter' or 'prescription-only' medicines has implications for patient safety, accessibility of medicines to patients and responsible management of health care expenditure. The decision on the prescription status and related supply conditions is a core competency of national health authorities.
} 
is an ongoing process in good cooperation with the EU European Medicines Agency (EMA). The European Pharmacopoeia ${ }^{27}$ is Europe's legal and scientific benchmark for pharmacopoeial standards which contribute to delivering high quality medicines in Europe and beyond.

\subsection{Substances of Human Origin}

The preparation, use and quality assurance of blood components also falls under the aegis of the EDQM. Council of Europe's activities in the field of blood transfusion started in the 1950s. They are built on the principles of the non-commercialisation of substances of human origin (voluntary and nonremunerated donation), mutual assistance and protection of donors and recipients. The activities concentrate on the ethical, legal and organisational aspects of blood transfusion with a view to ensuring safety, efficacy, quality, availability, and optimal use of blood supplies. The analyses include possible ethical and organisational impact of new scientific developments. Good Practice Guidelines for blood establishments are an integral part of the Guide to the Preparation, Use and Quality Assurance of Blood Components, jointly developed by the EDQM and the European Commission. ${ }^{28}$ The legal basis to this Guide was given in 1995 with Recommendation No R.95(15) (+ Appendix) of the Council of Europe's Committee of Ministers to member states on the preparation, use and quality assurance of blood components. ${ }^{29}$

Likewise, a Guide for the quality and safety of organ transplantation and a Guide for the quality and safety of tissues and cells for human application (cell therapy) are drawn up under the aegis of the EDQM. ${ }^{30}$

The EDQM Good Practice Guidelines are part of EU legislation. This way the Council of Europe Guides have become standard references in Europe and beyond, providing quality, safety and ethical guidance for professionals in the field.

27 Ph.Eur. — since mid-2016 in its 9th edition.

28 EU legislation requires from Member States to ensure that blood establishments take fully into account as of 15 February 2018 the standards and specifications set out in the guidelines when implementing their quality system, in line with Commission Directive (EU)2016/1214), following their adoption by the European Commission, the European Union and the European Economic Area.

2912 October 1995.

30 Organs, Tissues and Cells of Human Origin, Council of Europe Resolutions, Recommendations and Reports, 3rd Edition (2017). 
The principles guiding the work of the EDQM in the field of blood, organ, cell and tissue transplantation are:

- Ensuring human dignity, maintenance and realisation of human rights and fundamental freedoms;

- Protection of donor and recipient through the development of ethical, quality and safety standards in the field of organ, tissue and cell donation and human application;

- Non-commercialisation;

- Voluntary donation of materials of human origin;

- Fight against trafficking.

Organ shortages, or lack of access to a deceased donor programme, have encouraged organ trafficking, often involving patients seeking potential donors abroad. Although many countries allow non-resident living donation, there are variations in their approaches. They include the data collected, the screening and consent process, the reimbursement of loss of earnings and justifiable expenses (such as travel and medical costs) related to the donation procedure, and access to post-operative follow-up care. Assessing the validity of their consent to donation - which must be free, specific and informed - is vital. For protecting a non-resident living organ donor the Council of Europe has drawn up a special Resolution. ${ }^{31}$

\section{5}

\section{European Pillar of Social Rights}

The Preamble to the EU Treaty speaks of the Member States' wish to confirm "their attachment to fundamental social rights as defined in the European Social Charter (ESC) signed at Turin on 18 October 1961" (revised in 1996). The (revised) ESC is referred to in the Treaty on the functioning of the EU as one of the sources inspiring the social objectives of the EU. ${ }^{32}$ Yet, while applying the EU's binding standards in an area covered by the ESC, some Member States of the European Union have not accepted all provisions of the ESC provisions

\footnotetext{
31 CM Resolution 2017/1 on principles for the selection, evaluation, donation and follow-up of the non-resident living organ donors, 14 June 2017.

32 The Council of Europe's Committee of Social Rights tasked with the supervision of compliance with the ESC by States Parties to it routinely assesses whether national measures implementing EU law comply with the requirements of the Charter.
} 
establishing legally equivalent guarantees. ${ }^{33}$ This is the result of the choices made by each State Party to the Charter's acceptance system. Also, only fourteen EU member states have until now accepted the 1995 Protocol establishing a system of collective complaints under the ESC. ${ }^{34}$

As such, EU's accession to the ESC is indicated, if alone to avoid conflicts stemming from possible incompatibilities between Council of Europe and $\mathrm{EU}$ law. ${ }^{35}$ In this respect the Ec Social Pillar is relevant. On 26th April 2017, the European Commission adopted a proposal to establish a "European Pillar of Social Rights" (the so-called Turin process for the European Social Charter). The pillar is primarily conceived for the euro area, but applicable to all EU Member States wishing to be part of it. It was prepared by the European Commission in consultation with stakeholders at all levels, including the Secretary General of the Council of Europe. ${ }^{36}$ Health is part of the Pillar. ${ }^{37}$

The Pillar puts emphasis on new and more effective rights for citizens e.g. by linking economic and social rights. By establishing a European Pillar of Social Rights, the European Union intends to underline the relevance of social rights in its institutions and policies. As indicated by Nicoletti,

There is an urgent need to enhance existing synergies and find effective solutions to emerging conflicts. It must be ensured that the fundamental rights enshrined in the Charter are fully respected by decisions or legislation of the States Parties resulting directly or indirectly from changes in EU law. ${ }^{38}$

33 The 1961 Charter, the Additional Protocol of 1988, the Additional Protocol of 1995 and the Revised Charter of 1996.

34 European Social Charter and European Union Law, Council of Europe European Social Charter, www.Coe.int.

35 The ESC is referred to in the Treaty on the functioning of the EU and the Treaty on the EU as one of the sources of inspiration for the social objectives of the EU. The Preamble to the EU Treaty speaks of the Member States wish to confirm their attachment to fundamental social rights as in the ESC.

36 The Pillar initiative was presented by the European Commission at the Turin Forum on Social Rights in Europe organised by the Council of Europe in Turin on 18 March 2016.

37 European Pillar of Social Rights, Booklet.

38 Ms Michelle Niocoletti, Vice President Parliamentary Assembly, High Level Conference on the European Social Charter, Executive Summary, Council of Europe, October 2014, pp. 2, 3 . 
The Pillar text refers to Social Protection and Inclusion, under which heading health-, and long-term care are grouped:

- Para. 16: Healthcare: Everyone has the right to timely access to affordable, preventive and curative health care of good quality.

- Para. 18: Long term care: Everyone has the right to affordable long-term care services of good quality, in particular home-care and communitybased services.

To cite Secretary General Jagland of the Council of Europe:

To meet this challenge, we must promote legal certainty and coherence between European standard-setting systems protecting fundamental social rights. Ensuring that the European Social Charter, the Social Constitution of Europe, is central to the Pillar will contribute to this objective and make Europe not only more prosperous, but also more equitable and united. ${ }^{39}$

Economic freedoms should not be protected at the expense of the social right to healthcare. Instead, law- and policy-making in the EU should be systematically aligned with the requirements of the ESC in relation to health. ${ }^{40}$

Where Eu legislative instruments do not allow for frequent, fast revisions nor for legislation that goes further than its formal scope, the Council of Europe is well placed to fill the gaps. Both the Council of Europe and the European Union instigate convergence of national health policies and systems in Europe. The first with a preponderant emphasis on human rights. The second with more emphasis on economy and trade while protecting health, preventing disease and strengthening health systems. Sharing the same values and commitments, they are partners in promoting democracy and human rights.

39 Jagland, Opinion of the Secretary General of the Council of Europe on the European Union initiative to establish a European Pillar of Social Rights, Strasbourg, 2 December 2016.

40 European Parliament, Policy Department, Employment and Social Affairs, A European Pillar of Social Rights, First Reaction (Briefing), August 2016, p. 6. 
The EU could (and should) build more on Council of Europe standards when drawing up their legislation. Reinforced co-operation, avoiding duplication and inconsistencies, ${ }^{41}$ will provide for more coherence. It is for health lawyers to actively contribute to this vital European task.

\section{Henriette D.C. Roscam Abbing}

Professor Emerita of Health Law, Utrecht University, The Netherlands;

Editor, European Journal of Health Law

roscamabbing@zonnet.nl

41 Opinion of the Secretary General of the Council of Europe on the European Union initiative to establish a European Pillar of Social Rights, Council of Europe Strasbourg, 2 December 2016. 
